\title{
Pengaruh Jus Bayam terhadap Peningkatan Kadar Hemoglobin Ibu Hamil Trimester I dan II
}

\section{The Effect of Spinach Juice on the Increase in Hemoglobin Levels of Pregnant Women in the First and Second Trimesters}

\author{
Dian Zuiatna ${ }^{1}$, Elvi Era Liesmayani ${ }^{2}$, Reni Julia Tan $^{3}$ \\ ${ }^{1}$ Program Studi Profesi Bidan Fakultas Farmasi dan Kesehatan \\ Institut Kesehatan Helvetia Medan \\ ${ }^{2,3}$ Program Studi D4 Kebidanan Fakultas Farmasi dan Kesehatan \\ Institut Kesehatan Helvetia Medan \\ 1Email: dianzuiatna@helvetia.ac.id
}

\begin{abstract}
ABSTRAK
Salah satu ancaman yang dapat membahayakan ibu hamil dan janin adalah anemia. Di Indonesia, berdasarkan hasil Riskesdas tahun 2013, prevalensi anemia pada ibu hamil sebesar 37,1\%. Tujuan penelitian ini adalah untuk mengetahui pengaruh jus bayam terhadap peningkatan kadar hemoglobin pada ibu hamil trimester I dan II di Klinik Pratama Niar tahun 2020. Desain penelitian yang sesuai dengan penelitian ini adalah Quasi Eksperimen dengan menggunakan pendekatan One Group Pretest Posttest. Penelitian dilakukan pada bulan September tahun 2020. Sampel pada penelitian ini yaitu sebanyak 10 orang. Analisa uji statistik ini menggunakan uji t (Uji Paired Sampel T Test). Hasil dari penelitian ini menggunakan uji statistik didapatkan nilai $p$-value sebesar $0,000<0,05$, sehingga ada pengaruh antara pemberian jus bayam terhadap peningkatan kadar hemoglobin pada ibu hamil trimester I dan II. Berdasarkan hasil penelitian mengenai dampak jus bayam terhadap peningkatan kadar hemoglobin pada ibu hamil trimester I dan II di Klinik Pratama Niar tahun 2020, secara spesifik terdapat pengaruh antara pemberian jus bayam untuk meningkatkan kadar hemoglobin pada ibu hamil.
\end{abstract}

Kata Kunci: Jus Bayam, Hb, Ibu Hamil

\begin{abstract}
One of the threats that can harm pregnant women and fetuses is anemia. In Indonesia, in light of the consequences of Riskesdas in 2013, the pervasiveness of weakness in pregnant ladies was 37.1\%. The motivation behind this examination was to decide the impact of spinach juice on expanding hemoglobin levels in pregnant ladies in the first and second trimesters at the Niar Pratama center in 2020. The exploration plan in understanding with this investigation was a semi test utilizing the One Group Pretest Posttest approach. The study was conducted in September 2020. The sample in this study was 10 people. Analysis of this statistical test using the t test (Test Paired Sample T Test). The results of this study using statistical tests obtained a p-value of $0.000<0.05$, so that there is an effect between giving spinach juice to increasing hemoglobin levels in pregnant women in the second and second trimesters. In light of the aftereffects of examination on the effect of spinach juice on expanding hemoglobin levels in pregnant ladies in the first and second trimesters at the Niar Pratama Clinic in 2020, explicitly there is an impact between giving spinach juice to increment hemoglobin levels in pregnant ladies.
\end{abstract}

Keywords: Spinach Juice, Hb, Pregnant Women

\section{PENDAHULUAN}

Kekurangan zat besi pada

kehamilan adalah keadaan ibu dengan hemoglobin $(\mathrm{Hb})<11 \mathrm{~g} \%$ pada trimester pertama dan ketiga, sedangkan pada trimester kedua kadar hemoglobin $<10,5$ g\%. Anemia kehamilan disebut "potentional danger to mother and 
child" (potensi membahayakan bagi ibu dan anak), Itulah sebabnya anemia membutuhkan perhatian serius dari semua sektor yang terlibat dengan administrasi kesehatan. Anemia yang paling banyak dijumpai pada kehamilan adalah anemi defisiensi besi (Yuliani \& Musdalifah, 2017) .

Berdasarkan statistik dari WHO, prevalensi defisiensi besi pada ibu hamil secara keseluruhan adalah 41,8\%. Keadaan rendahnya jumlah trombosit merah (eritrosit) dalam tubuh disebut dengan defisiensi besi. Di Indonesia, seperti yang ditunjukkan oleh Riskesdas 2013, dominasi anemia pada ibu hamil adalah $37,1 \%$. Pemerintah melaksanakan program pengendalian anemia pada ibu hamil dengan pemberian 90 tablet $\mathrm{Fe}$ selama kehamilan untuk mengurangi anemia, namun angka kejadian anemia tetap tinggi (Rahmi \& Husna, 2020; Yuliani \& Musdalifah, 2017).

Anemia pada kehamilan sangat berbahaya bagi ibu dan janinnya. Akibat kekurangan zat besi pada ibu hamil adalah abortus, persalinan prematur, terhambatnya perkembangan dan perkembangan bayi dalam kandungan, mudah terinfeksi, ketuban pecah dini, selama persalinan dapat menyebabkan gangguan hisnya, persalinan pada kala I dapat berlangsung cukup lama dan terjadi partus terlantar, Selama menyusui dan pasca kehamilan terjadi subinvolusi uterus menyebabkan keluarnya cairan pasca kehamilan, yang dapat menyebabkan kematian (Pratiwi, 2019).

Salah satu upaya yang dilakukan oleh otoritas publik untuk mengurangi kejadian anemia adalah dengan memberikan 90 tablet zat besi $(\mathrm{Fe})$ selama kehamilan. Pada tahun 2017, angka cakupan 4.444 ibu hamil yang mengonsumsi 90 tablet zat besi di Sumatera Utara adalah $75,85 \%$. Oleh karena itu, dalam angka cakupan tablet besi yang diminum selama kehamilan, tidak mungkin mencapai target yang ditetapkan untuk tablet di $80 \%$ negara. Pemberian tablet besi tersebut diharapkan mampu mengatasi kasus anemia pada ibu hamil dan remaja putri serta meminimalisasikan dampak buruk akibat kekurangan Fe pada ibu hamil (Anggraini, Purnomo, \& Trijanto, 2018; Angrainy, 2017). Banyak tempat dan pusat kesehatan memberikan tablet zat besi pada ibu hamil. Terkadang tablet zat besi dikombinasikan dengan asam folat. Tablet zat besi dapat membuat ibu hamil mengalami konstipasi karena feses menjadi keras dan berwarna hitam 
menjadi penyebab tidak dikonsumsinya tablet zat besi tersebut (Sati, 2019).

Salah satu pilihan untuk memenuhi kebutuhan zat besi dapat dilakukan dengan mengkonsumsi sayuran yang berwarna hijau seperti bayam (Amaranthus spp). Mengkonsumsi daun bayam secara rutin, baik itu di sayur maupun dijadikan jus berkhasiat mampu mengatasi beberapa jenis penyakit salah satunya mencegah anemia karena bayam memiliki zat besi yang tinggi. Setiap 100 gram bayam mengandung 2,3 gram protein, 3,2 gram karbohidrat, 3 gram zat besi, dan 81 gram kalsium. Bayam juga kaya akan akan berbagai macam vitamin dan mineral, yakni vitamin $\mathrm{A}$, vitamin $\mathrm{C}$, niasin, thiamin, fosfor, riboflavin, natrium, kalium dan magnesium (Kundaryanti \& Widowati, 2019; Sari, Darmayanti, \& Ulfah, 2021).

Fungsi utama pada daun bayam adalah mendistribusikan oksigen ke seluruh tubuh dikarenakan kandungan zat besinya yang tinggi.

Manfaat lain dari zat besi ini adalah sebagai komponen sitokrom, protein mengganggu proses fotosintesis, sehingga sangat berguna bagi penderita anemia. Selain itu, bayam juga mengandung zat yang dapat mencegah oksidasi esensial dan fitokimia yang membantu melindungi tubuh terhadap berbagai penyakit (Farida, 2017).

Berdasarkan survey awal yang peneliti lakukan pada tanggal 21 Desember 2019 kepada 4 responden dalam pemeriksaan kehamilannya di Klinik Pratama Niar, di dapatkan informasi dari pemeriksaan fisik bahwa konjungtiva ibu pucat dan ibu mengeluh mudah lelah dan lesu. Dari hasil pemeriksaan kadar hemoglobin bahwa sebanyak 3 responden mengalami anemia, dari hasil anamnesa responden yang mengalami anemia mengatakan tidak rutin mengkonsumsi tablet tambah darah karena mengeluh susah BAB, dan 1 responden memiliki kadar hemoglobin normal, responden yang tidak menderita anemia mengatakan sering mengkonsumsi sayuran yang berwarna hijau. Penelitian ini bertujuan untuk mengetahui pengaruh jus bayam terhadap peningkatan kadar hemoglobin pada ibu hamil trimester I dan II di Klinik Pratama Niar tahun 2020. 


\section{METODE PENELITIAN}

Desain penelitian menggunakan Quasi Eksperimen dengan menggunakan pendekatan One Group Pretest Posttest yang dilakukan di Klinik Pratama Niar dimulai Januari - Desember 2020. Populasi dalam penelitian ini adalah ibu hamil trimester I dan II yang memeriksakan kehamilan dari bulan Juli - September tahun 2020 yaitu sebanyak 32 orang. Teknik dalam pengambilan sampel menggunakan purposive sampling dengan kriteria inklusi diantaranya: ibu hamil trimester I dan II, ibu hamil yang melakukan pemeriksaan kehamilan di Klinik Pratama Niar, ibu hamil yang bersedia menjadi responden dan ibu hamil dengan kondisi fisiologis, tanpa komplikasi dan tanpa penyakit bawaan sehingga jumlah sampel yang diperoleh sesuai dengan kriteria sebanyak 10 orang.

Penelitian ini terdiri dari 1 kelompok ibu hamil (trimester I dan II) yang disurvei $\mathrm{Hb}$ sebelumnya, kemudian setelah pemberian jus bayam. Jus bayam merah dibuat dengan mencampurkan 50 gram daun bayam dengan $150 \mathrm{ml}$ air mendidih untuk mendapatkan $200 \mathrm{ml}$ jus ( \pm 1 gelas besar). Pemberian jus bayam setiap hari sebelum sarapan (sekitar jam 7 pagi) selama 7 hari. Penilaian $\mathrm{Hb}$ menggunakan Easy touch dan lembar observasi dengan hasil ukur meningkat jika nilai $\mathrm{Hb}$ diperoleh $\geq 11$ gr $\%$ dan tidak meningkat jika nilai $\mathrm{Hb}$ diperoleh $<11$ gr \%. Analisis data terdiri dari analisis univariat dan bivariat, untuk uji statistik yang digunakan pada analisis bivariat adalah uji paired $T$ test.

\section{HASIL DAN PEMBAHASAN}

\section{Karakteristik Responden}

Tabel 1. Distribusi Frekuensi Berdasarkan Karakteristik Responden

\begin{tabular}{lll}
\hline Karakteristik Responden & N & \% \\
\hline Umur Ibu Hamil & & \\
20-35 tahun & 8 & 80 \\
>35 tahun & 2 & 20 \\
Pendidikan & & \\
SMP & 1 & 10 \\
SMA & 7 & 70 \\
PT & 2 & 20 \\
Pekerjaan & & \\
Tidak bekerja & 4 & 40 \\
Bekerja & 6 & 60 \\
\hline
\end{tabular}

Berdasarkan tabel 1. diperoleh mayoritas ibu memiliki umur 20-35 tahun sebanyak 8 orang $(80 \%)$, mayoritas derajat pendidikan SMA sebanyak 7 orang (70\%) dengan mayoritas bekerja sebanyak 6 orang $(60 \%)$. 


\section{Analisis Univariat}

Tabel 2. Distribusi Frekuensi Kadar $\mathrm{Hb}$ Sebelum dan Sesudah Diberikan Jus Bayam

\begin{tabular}{|c|c|c|c|c|c|}
\hline \multicolumn{3}{|c|}{$\begin{array}{c}\text { Sebelum diberikan } \\
\text { Jus Bayam }\end{array}$} & \multicolumn{3}{|c|}{$\begin{array}{c}\text { Sesudah diberikan } \\
\text { Jus Bayam }\end{array}$} \\
\hline $\begin{array}{c}\text { Kadar } \\
\text { Hb }\end{array}$ & $\mathbf{N}$ & $\%$ & $\begin{array}{c}\text { Kadar } \\
\text { Hb }\end{array}$ & $\mathbf{N}$ & $\%$ \\
\hline 10,3 gr\% & 1 & 10 & $11,1 \mathrm{gr} \%$ & & 10 \\
\hline 10,8 & 2 & 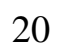 & & & 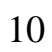 \\
\hline 12,3 & 1 & 10 & & 1 & 10 \\
\hline 12,5 & 1 & 10 & & 1 & 10 \\
\hline $7,4 \mathrm{gr} \%$ & 1 & 10 & $\%$ & 1 & 10 \\
\hline $7,6 \mathrm{gr} \%$ & 1 & 10 & $2,2 \mathrm{gr} \%$ & 1 & 10 \\
\hline $9,2 \mathrm{~g}$ & 1 & 10 & $2,3 \xi$ & 1 & 10 \\
\hline $9,5 \mathrm{~g}$ & 1 & 10 & $2,5 \mathrm{gr} \%$ & 1 & 10 \\
\hline $9,8 \mathrm{gr} \%$ & 1 & 10 & $12,9 \mathrm{gr} \%$ & 1 & 10 \\
\hline & & & $14,1 \mathrm{gr} \%$ & 1 & 10 \\
\hline
\end{tabular}

Hasil tabel 2. diperoleh sebelum diberikan jus bayam 2 orang memiliki kadar $\mathrm{Hb} \geq 11$ gr \%, dan selebihnya sebanyak 8 orang memiliki kadar $\mathrm{Hb}<$ $11 \mathrm{gr} \%$. Kemudian setelah diberikan jus bayam diperoleh adanya peningkatan kadar $\mathrm{Hb}$ pada 10 ibu hamil dengan rentang 11-14 gr\%.

\section{Analisis Bivariat}

\section{Uji Normalitas Shapiro-Wilk}

Tabel 3. Hasil Uji Normalitas ShapiroWilk

\begin{tabular}{lc}
\hline \multirow{2}{*}{ Kadar Hemoglobin } & $\begin{array}{c}\text { Shapiro- } \\
\text { Wilk }\end{array}$ \\
\cline { 2 - 2 } & Sig \\
\hline Sebelum diberikan jus bayam & 0,628 \\
Setelah dberikan jus bayam & 0,355 \\
\hline
\end{tabular}

Hasil uji normalitas data dengan Shapiro-wilk dapat diambil kesimpulan bahwa dengan nilai sig 0,628 untuk sebelum dan 0,355 untuk setelah dibeirkan > 0,05 maka data tersebut berdistrubusi normal.

\section{Uji Paired T Test}

Tabel 4. Hasil Uji Paired Samples T-Test pengaruh jus bayam terhadap peningkatan kadar hemoglobin ibu hami Trimester I dan II

\section{Kadar Hemoglobin \\ sig (2-tailed)}

Kadar Hemoglobin Sebelum
dibeirkan jus bayam - Kadar
Hemoglobin Setelah
dibeirkan jus bayam

Berdasarkan tabel 4. diketahui dilihat bahwa nilai dari $p$-value $0,000<$ 0,05 , sehingga dapat diambil kesimpulan bahwa ada pengaruh yang signifikan antara pemberian jus bayam terhadap peningkatan kadar hemoglobin pada ibu hamil Trimester I dan II di Klinik Pratama Niar tahun 2020.

Berdasarkan hasil penelitian menunjukkan bahwa nilai dari p-value $0,000<0,05$, sehingga dapat diambil kesimpulan bahwa ada pengaruh yang signifikan antara pemberian jus bayam terhadap peningkatan kadar hemoglobin pada ibu hamil trimester I dan II di Klinik Pratama Niar tahun 2020.

Hasil ini sejalan dengan penelitian yang dilakukan oleh Titik Wijayanti tahun 2016 dengan judul 
"Perbaikan Status Hb (Hemoglobin) Ibu Hamil Trimester Pertama Dengan Jus Daun Bayam (Amaranthus tricolor,L)". Konsekuensi dari uji ordinaris dan homogenitas menunjukkan bahwa informasi disesuaikan secara teratur dan variasi informasi homogen. (Wijayanti, 2016). Sementara itu, hasil uji $t$ gabungan menunjukkan nilai (2-tailed) adalah $0,000<\mathrm{p}(0,05)$ yang berarti ada perbedaan kadar $\mathrm{Hb}$ sebelumnya, kemudian setelah pemberian jus bayam. Hal ini menunjukkan bahwa jus daun bayam ampuh dalam meningkatkan kadar $\mathrm{Hb}$ pada ibu hamil trimester pertama (Wijayanti, 2016).

Penelitian ini juga sesuai dengan penelitian yang diarahkan oleh Ramadhani, dkk. Ditemukan bahwa penggunaan jus bayam merah berpengaruh terhadap peningkatan kadar hemoglobin pada ibu hamil trimester II di Desa Bandar Klippa, Kec. Percut Sei Tuan Kab. Deli Serdang tahun 2020 dengan hasil uji faktual Asym sig Asym sig (2-tailed) 0,000 dibawah 0,05 (Nasution, Aisyah, \& Harahap, 2021).

Berdasarkan penelitian yang dilakukan oleh Novie Merida dkk, dengan judul "Efektifitas Terapi Kombinasi Jus Bayam dan Tomat Terhadap Peningkatan Kadar
Hemoglobin Pada Ibu Hamil Dengan Anemia" Berdasarkan penelitian yang telah dilakukan diwilayah kerja Puskesmas Sail, didapatkan hasil uji statistik dengan menggunakan uji $t$ independent diperoleh $\mathrm{p}(0,013)<\mathrm{a}$ $(0,05)$. Hal ini menunjukkan bahwa terdapat perbedaan yang mencolok antara rerata kadar hemoglobin ibu hamil dengan kelemahan pada kelompok uji dan kelompok pembanding setelah diberikan perlakuan campuran perasan bayam dan tomat sehingga cenderung disimpulkan bahwa penyelenggaraan perlakuan campuran pemberian jus bayam dan tomat dapat meningkatkan kadar hemoglobin ibu hamil yang mengalami anemia (Merida \& Utomo, 2014).

Jus bayam merupakan salah satu sayuran olahan yang memiliki banyak manfaat bagi tubuh masyarakat, salah satu kandungan bayam adalah zat besi. Zat besi dalam bayam dapat dimanfaatkan sebagai keputusan obat untuk membangun kadar hemoglobin ibu hamil. Kapasitas zat besi adalah untuk membingkai trombosit merah, sehingga pembentukan trombosit merah dalam tubuh cukup, sehingga kadar hemoglobin akan normal (Fathurrahman, 2021; Parulian, 2018). 
Makanan dan minuman merupakan kebutuhan pokok yang sangat dibutuhkan oleh orang setiap hari dan makanan juga perlu diolah dengan baik untuk mendapatkan manfaat yang dibutuhkan oleh tubuh. Bayam olahan dengan jus merupakan minuman yang dapat meningkatkan kadar hemoglobin karena pada dasarnya banyak mengandung zat besi cukup tinggi yaitu sebesar 3,9 mg per $100 \mathrm{~g}$. Peranan zat besi adalah untuk membentuk sel darah merah, jika produksi sel darah merah dalam tubuh mencukupi maka kadar hemoglobin dalam darah manusia juga akan normal.

Menurut asumsi peneliti berdasarkan karakteristik responden, usia ibu pada saat hamil juga mempengaruhi status kesehatan dan keselamatan kehamilan. Usia yang kurang produktif akan mempengaruhi kerja system dalam tubuh. Dari 10 responden satu responden yang berusia 38 tahun tidak mengalami peningkatan kadar hemoglobin, usia 38 tahun merupakan usia yang kurang produktif dan usia resiko tinggi untuk hamil meskipun ada pengaruh lain yang menyebabkan kadar hemoglobin responden tersebut tidak meningkat. Terlepas dari usia, kualitas dalam ujian ini adalah pelatihan. Pendidikan instruktif akan membentuk perspektif individu, termasuk kapasitas untuk memahami faktor yang diidentifikasi dengan kesejahteraan dan penggunaan mereka sendiri informasi untuk memastikan dan menjaga kesehatan. Karakteristik yang terakhir pada penelitian ini yakni pekerjaaan, dalam penelitian ini status pekerjaan tidak berpengaruh terhadap peningkatan kadar hemoglobin karena hasil penelitian ini menunjukkan bahwa meskipun ibu bekerja sebagai penjahit, pedagang, karyawan swasta dan guru setelah minum jus bayam setiap hari selama 7 hari, kadar hemoglobin ibu terus meningkat.

Kekurangan kadar hemoglobin yang dapat mengakibatkan anemia pada kehamilan menjadi kasus yang sangat berbahaya seperti abortus, perdarahan bahkan dapat mengakibatkan kematian yang disebabkan oleh anemia itu sendiri. penatalaksaan anemia pada kehamilan dapat menggunakan terapi farmakologi, akan tetapi mengkonsumsi zat kimia yang ada pada obat farmakologi ini ada beberapa efek samping yang akan dialami oleh tubuh. Dalam hal ini alternatif agar kadar hemoglobin pada darah tetap normal tanpa ada efek 
samping, yakni ibu-ibu hamil dapat mengkonsumsi terapi nonfarmakologis salah satunya yaitu mengkonsumsi jus bayam. Karna kandungan zat besi dalam bayam cukup tinggi untuk meningkatkan kadar hemoglobin darah. Ibu hamil dengan suplementasi zat besi yang cukup otomatis akan terhindar dari defisiensi zat besi yang akan menyebabkan kesehatan ibu menurun, bahkan dapat mengancam keselamatan janin ibu.

Berdasarkan hasil penelitian ini dari 10 responden yang diberikan jus bayam selama 7 hari ada satu responden yang tidak mengalami kenaikan kadar hemoglobin. Dari hasil wawancara yang peneliti lakukan responden menyatakan bahwa, selama beberapa hari terakhir responden tidak nafsu makan dan pada malam hari tidak bisa tidur karena ada permasalahan dengan suaminya sehingga responden mengalami setres. Dari kasus tersebut peneliti dapat mengambil kesimpulan bahwa untuk meningkatkan status kesehatan seseorang bukan hanya dipengaruhi oleh asupan makanan atau gizi akan tetapi keadaan psikologis ibu juga harus baik sehingga ibu perlu mendapatkan dukungan dari keluarga dan lingkungan sekitar juga sangatlah berpengaruh.

\section{SIMPULAN DAN SARAN}

Penelitian ini dapat disimpulkan bahwa ada pengaruh pemberian jus bayam terhadap kadar $\mathrm{Hb}$ yaitu adanya peningkatan kadar $\mathrm{Hb}$ hamil trimester I dan II di Klinik Niar setelah diberikan intervensi. Bagi pihak klinik diharapkan mampu meningkatkan dan tetap mempertahankan upaya dalam hal promotif dan preventif terutama mengenai pelayanan antenatal. Upaya yang dapat dilkukan yakni dapat berupa anjuran untuk mengkonsumi zat besi untuk membantu meningkatkan kadar hemoglobin pada ibu hamil, salah satu cara agar ibu dapat meningkatkan kadar hemoglobinnya yakni dengan mengkonsumsi jus bayam.

\section{DAFTAR PUSTAKA}

Anggraini, D. D., Purnomo, W., \& Trijanto, B. (2018). Interaksi Ibu Hamil dengan Tenaga Kesehatan dan Pengaruhnya terhadap Kepatuhan Ibu Hamil Mengonsumsi Tablet Besi (Fe) dan Anemia di Puskesmas Kota Wilayah Selatan Kota Kediri. Buletin Penelitian Sistem Kesehatan, 21(2), 89-92.

Angrainy, R. (2017). Hubungan Pengetahuan dengan Sikap Ibu Hamil dalam Pencegahan Anemia Pada Kehamilan Di Puskesmas Rumbai Bukit Tahun 2016. Jurnal Endurance: Kajian Ilmiah Problema Kesehatan, 2(1), 62-67. 
Farida, U. (2017). Bayam Merah untuk Peningkatan Kadar Hemoglobin Remaja Putri Kelas XII. Jurnal Smart Keperawatan, 4(1).

Fathurrahman, T. (2021). Edukasi Pentingnya Konsumsi Sayur dan Buah Pada Siswa Sekolah Dasar Negeri 2 Soropia Kecamatan Soropia Kabupaten Konawe. KRIDA CENDEKIA, 1(03).

Kundaryanti, R., \& Widowati, R. (2019). Pengaruh Pemberian Jus Bayam Hijau Terhadap Peningkatan Kadar Hemoglobin pada Ibu Hamil Anemia Di Wilayah Kerja Puskesmas Pasar Minggu Jakarta Selatan Tahun 2018. Jurnal Ilmu Keperawatan Dan Kebidanan Nasional, 1(1).

Merida, N., \& Utomo, W. (2014). Efektifitas terapi kombinasi jus bayam dan tomat terhadap peningkatan kadar hemoglobin pada ibu hamil dengan anemia. Jurnal Online Mahasiswa Perpustakaan Fakultas Keperawatan, 1(2).

Nasution, R. S., Aisyah, S., \& Harahap, H. P. (2021). Konsumsi Jus Bayam Merah dapat Meningkatkan Kadar Hemoglobin pada Ibu Hamil Trimester II. JKM (Jurnal Kebidanan Malahayati), 7(2), 215221.
Parulian, I. (2018). Strategi dalam Penanggulangan Pencegahan Anemia pada Kehamilan. Jurnal Ilmiah Widya, 4(3).

Pratiwi, A. M. (2019). Patologi Kehamilan. Yogyakarta: Pustaka Baru Press.

Rahmi, N., \& Husna, A. (2020). Analisis Faktor Anemia pada Ibu Hamil di Wilayah Kerja Puskesmas Baitussalam Kabupaten Aceh Besar. JOURNAL OF HEALTHCARE TECHNOLOGY AND MEDICINE, 6(2), 1250-1264.

Sari, Y. O., Darmayanti, D., \& Ulfah, M. (2021). Pengaruh Pemberian Zat Besi Dan Sayur Bayam Terhadap Peningkatan Kadar Hemoglobin Ibu Hamil Dengan Anemia Di Wilayah Kerja Puskesmas Martapura I. JURNAL KEPERAWATAN SUAKA INSAN (JKSI), 6(1), 19-26.

Sati. (2019). Buku Pintar Kehamilan. Yogyakarta: Brilian Books.

Wijayanti, T. (2016). Perbaikan status $\mathrm{Hb}$ (Hemoglobin) pada ibu hamil trimester pertama dengan jus daun bayam (Amaranthus Tricolor. L). Edubiotik: Jurnal Pendidikan, Biologi Dan Terapan, 1(01), 30-34.

Yuliani, D. R., \& Musdalifah, U. (2017). Buku Ajar Aplikasi Asuhan Kehamilan. Jakarta: CV Trans Info Media. 